\title{
A new polymethylmetacrylate membrane improves the membrane adhesion of blood components and clinical efficacy
}

Ikuto Masakane ${ }^{1}$, Shiho Esashi ${ }^{1}$, Asami Yoshida ${ }^{1}$, Tetsuro Chida ${ }^{1}$, Hiroaki Fujieda ${ }^{2 *}$, Yoshiyuki Ueno ${ }^{2}$ and Hiroyuki Sugaya ${ }^{2}$

\begin{abstract}
Background: Hemodialysis with polymethylmetacrylate (PMMA) membrane dialyzers allows unique protein adsorption. New PMMA dialyzers should demonstrate equivalent protein adsorption, but improved hemocompatibility.

Methods: Platelet adhesion and activation and protein adsorption were determined for the new PMMA membrane dialyzer Filtryzer ${ }^{\oplus} \mathrm{NF}(\mathrm{NF})$ and conventional Filtryzer ${ }^{\oplus} \mathrm{BG}(\mathrm{BG})$ in vitro. In clinical study, six subjects were treated with $\mathrm{NF}$ and BG for 3 months each in a crossover design. Three months after the use of each dialyzer, solute removal, hemocompatibility, peripheral circulation by skin perfusion pressure (SPP), and other dialysis-related side effects were also compared.

Results: Protein adsorption pattern was similar on NF and BG, but platelet adhesion and activation were much lower on NF in vitro. Clinically, NF and BG removed equivalent amounts of small molecule solutes and low-molecular-weight proteins. The platelet count and peripheral circulation were stable during dialysis with NF, whereas both were decreased during dialysis with BG. The percent changes in SPP were significantly smaller with NF compared with BG. Data on the dialysis-related side effects were no significant differences in any individual items or in the mean total score for the two groups, but the mean score of the seven items tended to be lower with NF. Protein adsorption by the membranes is considered one factor associated with clinically improvements. But activated platelets induce the aggregation of platelets, leukocytes, and erythrocytes, which can interfere with peripheral circulation during dialysis. Decreased peripheral circulation causes dialysis-related side effects. Therefore reduced platelet activation during dialysis by NF may be significant in improving the prognosis of patients, as well as reducing the frequency of side effects.

Conclusions: The new PMMA membrane dialyzer NF shows substantially improved hemocompatibility. We expect this product will improve the condition of chronic dialysis patients.
\end{abstract}

Trial registration: UMIN000024955

Keywords: Dialysis, PMMA membrane, Protein adsorption, Hemocompatibility

\footnotetext{
* Correspondence: Hiroaki_Fujieda@nts.toray.co.jp

${ }^{2}$ Advanced Materials Research Labs, Toray Industries, Inc., 2-2 Sonoyama

3-chome, Otsu, Shiga, Japan

Full list of author information is available at the end of the article
} 


\section{Background}

Hemodialysis with polymethylmetacrylate (PMMA) dialyzers allows unique protein adsorption $[1,2]$. Clinically, hemodialysis with PMMA dialyzers is associated with the relief of dialysis-induced itching [3, 4] and improvement of nutrition [5]. A new PMMA dialyzer was developed to improve hemocompatibility while maintaining the amount of protein adsorption. The present study aimed to determine the basic properties of the new membrane and its performance in solute removal and peripheral circulation under standard clinical conditions.

\section{Methods}

\section{Subjects}

We evaluated the new PMMA dialyzer; "Filtryzer ${ }^{\circledR}$ NF" (NF) and compared it with the conventional PMMA dialyzer; "Filtryzer ${ }^{\circledast} \quad$ BG" (BG). The performance of the dialyzers were compared in experimental and clinical studies. For the testing in vitro, hollow fiber membranes were cut from the dialyzers and used as samples. For the clinical testing, dialyzers with a $1.6 \mathrm{~m}^{2}$ membrane surface area were used. Technical data on BG and NF are summarized in Table 1.

\section{Membrane analysis \\ Blood component adhesion}

The hollow fiber membranes were longitudinally cut to expose the inner surface and then incubated with fresh human whole blood containig $50 \mathrm{U} / \mathrm{mL}$ of heparin (Heparin Sodium Injection, Ajinomoto, Tokyo, Japan) for $1 \mathrm{~h}$ at $37{ }^{\circ} \mathrm{C}$ with continuous agitation. After washing with phosphate-buffered saline (PBS), the samples were fixed with $25 \%$ glutaraldehyde (Sigma-Aldrich) and observed by field emission scanning electron microscopy (S-800, Hitachi High-Tech Fielding Corp., Tokyo, Japan) to count the number of adhered

Table 1 Technical data on BG and NF

\begin{tabular}{llll}
\hline & & BG & NF \\
\hline Ultrafiltration rate $^{\text {a }}[\mathrm{mL} / \mathrm{h} \mathrm{mmHg}]$ & 38 & 35 \\
Clearance $^{\mathrm{b}}[\mathrm{mL} / \mathrm{min}]$ & Urea & 191 & 193 \\
& Creatinine & 174 & 180 \\
& Phosphate & 164 & 172 \\
& Vitamin B & 126 \\
Negative charge & & 114 & 126
\end{tabular}

aUltrafiltration rate was measured with bovine blood (hematocrit,

$30 \pm 3 \%$; total protein, $6.0 \pm 0.5 \mathrm{~g} / \mathrm{dl}$; blood flow rate, $200 \pm 4 \mathrm{~mL} / \mathrm{min}$; transmembrane pressure, $13.3 \pm 1.3 \mathrm{kPa}$; temp., $37 \pm 1{ }^{\circ} \mathrm{C}$

${ }^{\mathrm{b}}$ Clearance was measured with aqueous solution. Blood flow rate, $200 \pm 4 \mathrm{~mL}$ / $\mathrm{min}$; dialyzate flow rate, $500 \pm 10 \mathrm{~mL} / \mathrm{min}$, filtration rate, $10 \pm 2 \mathrm{~mL} / \mathrm{min}$; temp., $37 \pm 1{ }^{\circ} \mathrm{C}$

${ }^{\mathrm{C}}$ Negative charge on the membranes was determined from the evaluation of the triiodide complex. It was created by the reaction of iodine and iodide ions after dried hollow fiber membrane immersed in a solution of $5 \%$ potassium iodide in methanol for $24 \mathrm{~h}$ platelets. The blood was obtained from volunteers after ethical review and approval by Toray Industries, Inc.

\section{Activation of platelets}

We prepared the mini modules of NF, BG. The mini-module had a length of $120 \mathrm{~mm}$ and a diameter of $5 \mathrm{~mm}$, and contained 48 hollow fibers. Membrane surface area of mini module was $3619 \mathrm{~mm} 2.6 .5 \mathrm{~mL}$ of fresh human blood, including the $15 \%$ acid citrate dextrose solution (ACD) as an anti-coagulant, was circulated to it at 1.0 $\mathrm{mL} / \mathrm{min}$ for $30 \mathrm{~min}$. The collected blood was allowed to stand in ice water for $15 \mathrm{~min}$ and centrifuged at $2000 \mathrm{~g}$ at $4{ }^{\circ} \mathrm{C}$ for $30 \mathrm{~min}$. The $\beta$-thromboglobulin $(\beta-\mathrm{TG})$ concentration in the resulting plasma was determined by the enzyme immunoassay (EIA) method.

\section{Electrophoresis of the adsorbed proteins}

We prepared the mini modules of polysulfone membrane dialyzer "Toraylight ${ }^{\oplus} \mathrm{NV}-\mathrm{U}$ " as a reference, in addition to $\mathrm{NF}$ and BG. $6.5 \mathrm{~mL}$ of human serum (Human Serum type $\mathrm{AB}$, Sigma-Aldrich) was circulated to it at $1.0 \mathrm{~mL} / \mathrm{min}$ for 4 h. After circulation, the column was washed with $20 \mathrm{~mL}$ of PBS. The hollow fiber membranes were removed and cut into 5-mm-long pieces, which were then immersed in 50\% acetic acid (017-00251, Wako Pure Chemical Industries, Ltd., Osaka, Japan) for $24 \mathrm{~h}$ to extract the adsorbed proteins. The extracted samples were freeze-dried and dissolved in PBS. We determined the quantity of protein in the samples using the BCA Assay (Pierce BCA Protein Assay Kit, Takara Bio, Otsu, Japan). Next, the samples were processed into aliquots with $0.2 \mathrm{~g}$ of protein each in the same volume of sample buffer (Tris-aspartic acid sample buffer, TEFCO, Aomori, Japan) and were heated at $95{ }^{\circ} \mathrm{C}$ for $5 \mathrm{~min}$. The samples were electrophoresed through a gel (4-12\% LS-PAGE mini, TEFCO) at $100 \mathrm{~V}$ for $1 \mathrm{~h}$ in Tris-aspartic acid running buffer (TEFCO). The gels were stained with Coomassie Brilliant Blue (PhastGel Blue R 40Tablets, Pharmacia Biotech, Uppsala, Sweden) and silver staining (Silver Staining II Kit, Wako) and then imaged.

\section{Clinical study \\ Subjects}

Six anuric patients (five males and one female) with no inflammatory signs who were on maintenance dialysis were enrolled. Subject characteristics included a mean age of $69 \pm 16$ years and a mean duration of dialysis therapy of $9.1 \pm 2.5$ years. Underlying conditions were glomerulonephritis in two patients, nephrosclerosis in two, diabetic nephropathy in one, and unknown in one. All subjects had undergone hemodialysis with Filtryzer ${ }^{\bullet}$ BK (BK) before enrolling in the study. All patients were confirmed to have no clinical findings or data on the ankle-brachial pressure index $(\mathrm{ABI})$, which is indicative of arterial stenosis or obstruction of the lower 
extremities, or a past history of arteriosclerosis obliterans. This clinical study was approved by the ethical committee of Yabuki Hospital (Authorization No. 30), and documented informed consent was obtained from each patient.

\section{Methods}

As shown in Fig. 1, the six subjects were treated with NF and BG for 3 months each in a crossover design. The last dialysis treatment using each dialyzer for 3 months, the amount of solute removal, percent changes in platelet count during dialysis, changes in peripheral circulation, and any dialysis-related complaints from the patients were evaluated. The prescription dialysis was performed with a blood flow rate of $270 \mathrm{~mL} / \mathrm{min}$, dialyzate flow rate of $500 \mathrm{~mL} / \mathrm{min}$, and dialysis time of $4 \mathrm{~h}$. The solute removal capacity was evaluated based on the percent reduction of the blood concentrations of urea nitrogen, creatinine, uric acid, inorganic phosphorus, $\beta_{2}$ microglobulin $\left(\beta_{2} \mathrm{MG}\right)$, and $\alpha_{1}$ microglobulin $\left(\alpha_{1} \mathrm{MG}\right)$ and the total amounts of albumin in the effluent dialyzate. The peripheral circulation was evaluated with PAD-3000 (Kaneka Medix, Osaka, Japan). The skin perfusion pressure (SPP) of the sole of the right foot [6] was measured before dialysis and at every hour during dialysis, and the rate of change was evaluated based on the value before dialysis. SPP measurement was performed twice a week with each dialyzer. In addition, at the same time of SPP measurement, systolic blood pressure was also measured.

Dialysis-related side effects, including itching, distraction, malaise, headache, hypotension, fatigue after dialysis, and appetite, were evaluated for each dialyzer. Each side effect was evaluated on a 5 -grade scale $(0-4)$, with lower scores meaning fewer complaints.

\section{Statistical analysis}

Student's $t$ tests were used to compare activation of platelets in vitro and laboratory results from the clinical

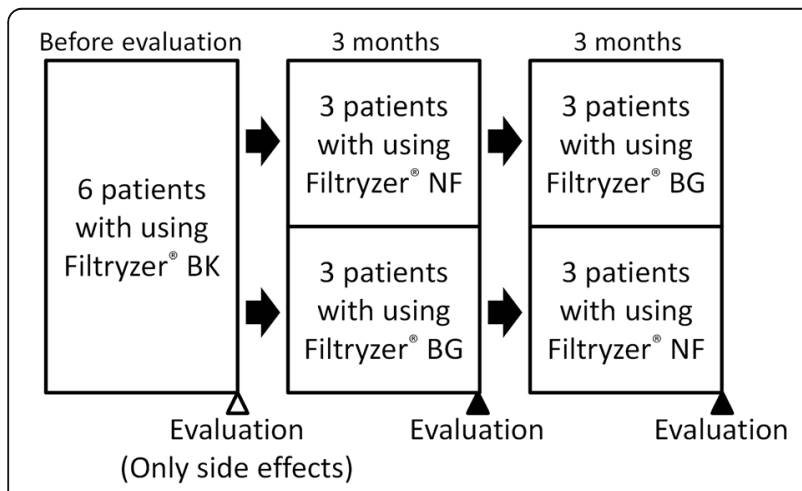

Fig. 1 The design of clinical study study between groups. Results of the investigation of unidentified complaints were tested with Friedman's test. The analytical data are shown as the mean \pm standard deviation. $P$ values $<0.05$ were considered statistically significant.

\section{Results}

\section{Membrane analysis}

The number of adhered platelets in vitro was at least 100fold lower on NF than on BG (Fig. 2). When the $\beta$-TG level, as a platelet activation marker, was evaluated in vitro, that of NF was 30\% lower than BG (Fig. 3). The molecular weights of the proteins adsorbed on NF and BG were nearly equivalent, as assessed by electrophoresis (Fig. 4).

\section{Clinical study}

The percent reduction of small molecules and lowmolecular-weight proteins in the blood before and after dialysis is shown in Fig. 5, and the total amount of albumin in the effluent dialyzate is shown in Fig. 6. There were no significant differences in any of these parameters between NF and BG.

During dialysis, the percent changes in platelet count were (for NF and BG, respectively) 97.1 and $86.1 \%$ after 15 min of dialysis, 96.5 and $85.1 \%$ after $30 \mathrm{~min}, 97.3$ and 88.3\% after $1 \mathrm{~h}$, and 99.6 and $90.1 \%$ after $4 \mathrm{~h}$. The changes in platelet count during dialysis were significantly smaller with NF than with BG (Fig. 7).

The systolic blood pressure during dialysis was shown in Fig. 8a. There were no significant difference between NF and BG, and no cases of intradialytic hypotension which required intervention.

Peripheral circulation was evaluated through changes in SPP during dialysis and compared between groups. The SPP values were $69.6 \pm 12.2 \mathrm{mmHg}$ before the start of dialysis, $69.8 \pm 11.5 \mathrm{mmHg}$ after $1 \mathrm{~h}$ (percent change, $+0.6 \pm$ $7.7 \%), \quad 70.4 \pm 10.0 \mathrm{mmHg}(+1.7 \pm 9.7 \%)$ after $2 \mathrm{~h}, 67.7$ $\pm 14.4 \mathrm{mmHg}(-2.8 \pm 11.8 \%)$ after $3 \mathrm{~h}$, and $64.6 \pm 14.5 \mathrm{mmHg}$ $(-7.7 \pm 11.1 \%)$ after $4 \mathrm{~h}$ with NF, indicating that the SPP was maintained and did not significantly change during dialysis. With BG, the SPP values were $77.7 \pm 10.4 \mathrm{mmHg}$ before the start of dialysis, $71.4 \pm 14.2 \mathrm{mmHg}(-7.6 \pm 16.5 \%)$ after $1 \mathrm{~h}$, $66.9 \pm 12.7 \mathrm{mmHg}(-13.4 \pm 15.6 \%)$ after $2 \mathrm{~h}, 65.4 \pm$ $10.4 \mathrm{mmHg}(-15.7 \pm 9.9 \%)$ after $3 \mathrm{~h}$, and $63.6 \pm 9.6 \mathrm{mmHg}$

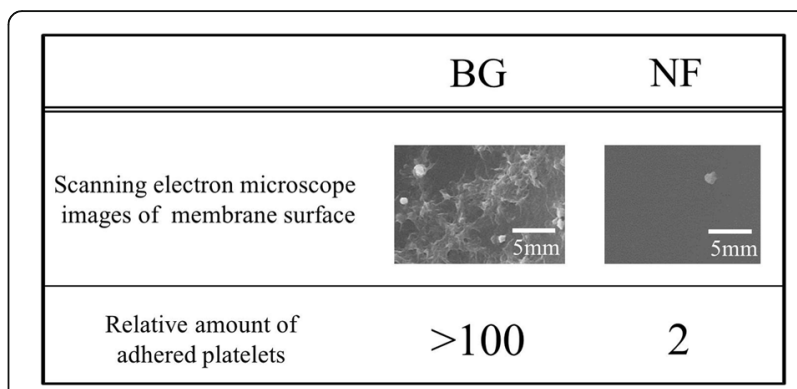

Fig. 2 The number of adhered platelets on NF and BG in vitro 


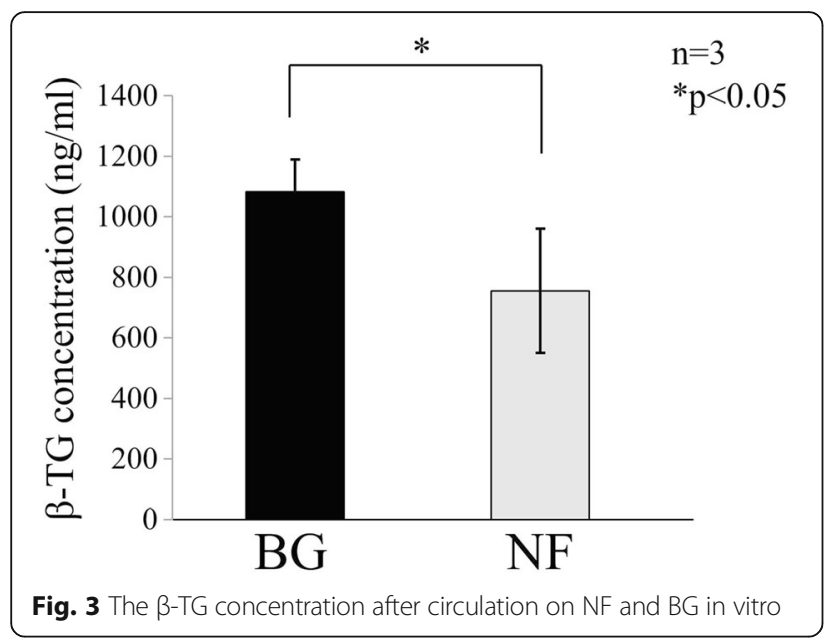

$(-17.9 \pm 9.4 \%)$ after $4 \mathrm{~h}$, indicating significant decreases in the SPP after 3 and $4 \mathrm{~h}$ compared with before starting dialysis. The percent changes in SPP were significantly smaller at 2 and $3 \mathrm{~h}$ with NF compared with BG (Fig. 8b).

Data on the dialysis-related side effects are shown in Fig. 9. There were no significant differences in any individual items or in the mean total score for the two groups, but the mean score of the seven items tended to be lower with NF.

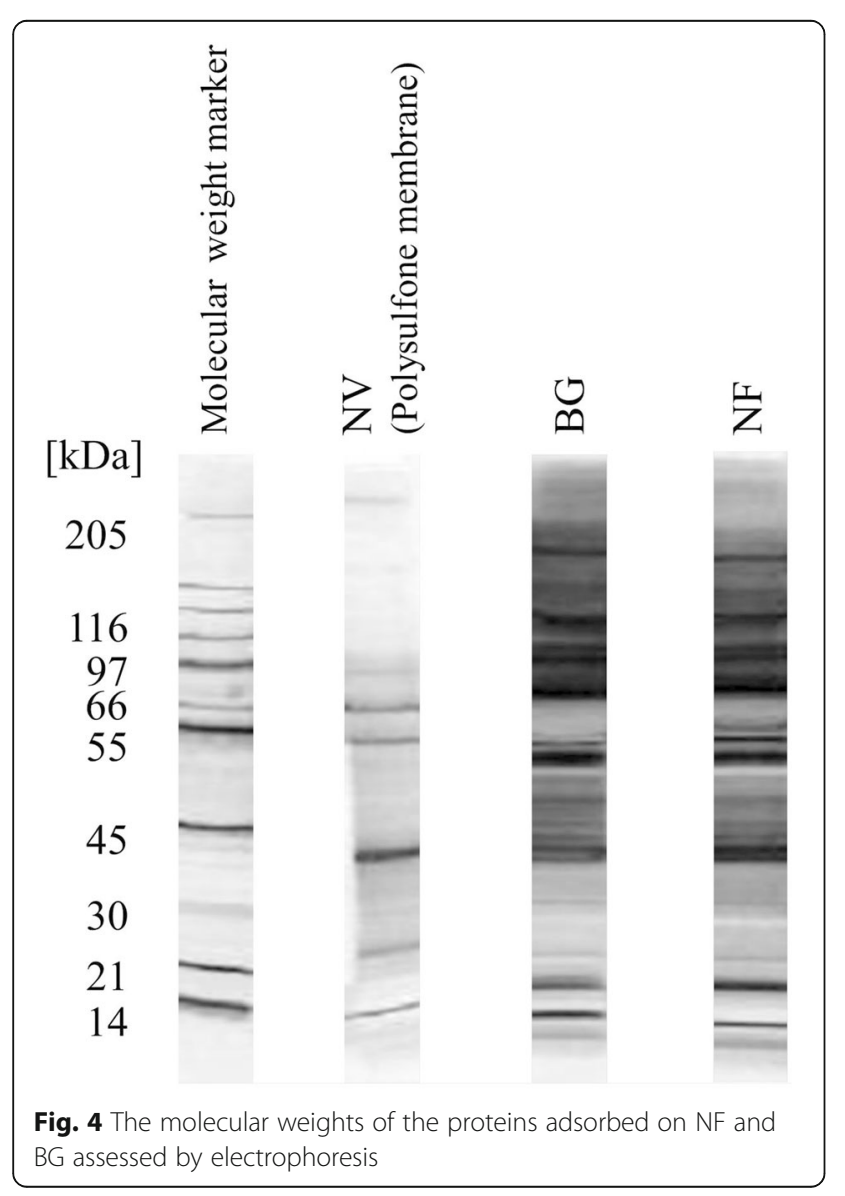

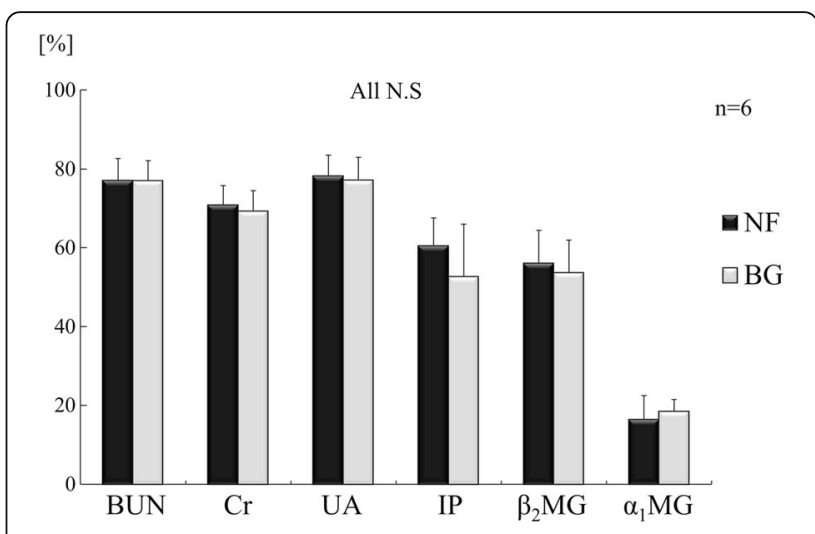

Fig. 5 The percent reduction of small molecules and low-molecularweight proteins in the blood before and after dialysis

\section{Discussion}

The number of adhered platelets on NF was at least 100-fold lower than that on BG (Fig. 2), and the platelet activation of NF was 30\% lower than that of BG (Fig. 3). On the other hand, no substantial differences were found in the amount of adsorbed proteins or their molecular weight between NF and BG. These results indicate that protein adsorption pattern by the hollow fiber NF was similar to that of BG (Fig. 4). (Although the used blood in this electrophoresis experiment was not of

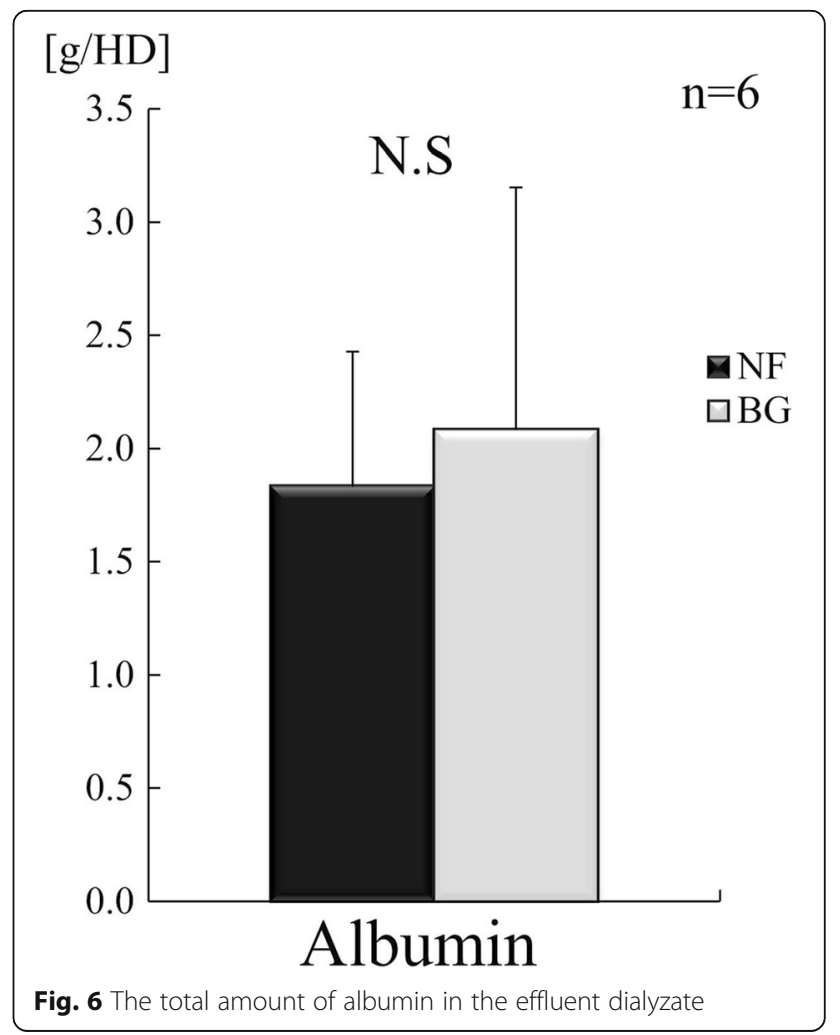




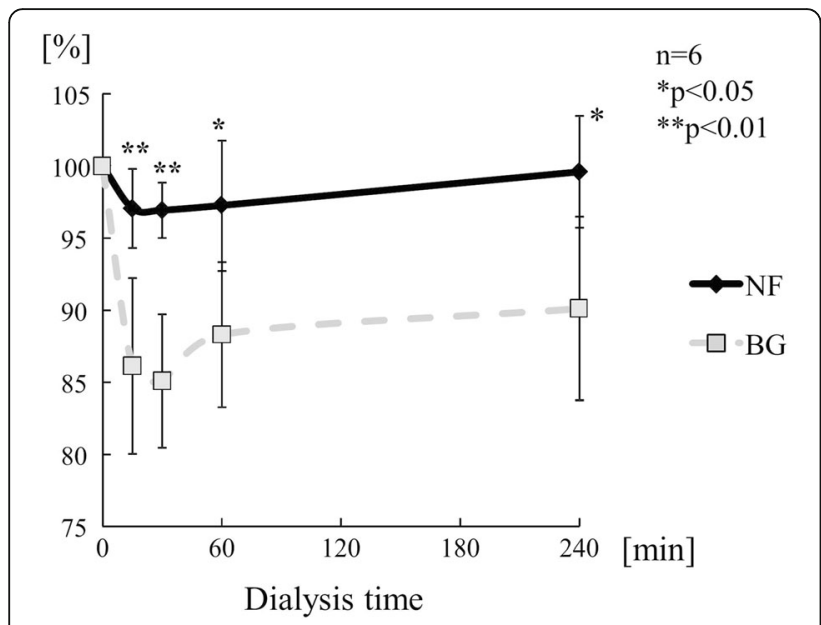

Fig. 7 The changes in platelet count during dialysis with NF and BG

hemodialysis patients, NF and BG would have approximately the same adsorption pattern even when the same experiment is performed on the blood of hemodialysis patients.) Comparing NF to BG in the clinical setting, the two dialyzers showed equivalent solute removal (Figs. 5 and 6). However, changes in the platelet count during dialysis confirmed reduced platelet adhesion to NF (Fig. 7). It was considered that BG and NF have almost the same adsorption and fractionation characteristics, which suggested that the membrane structure of BG and NF are equivalent. The difference between the two membranes is only the electrostatic charge (Table 1 ). Since NF has a less negative charge than BG, the electrostatic interaction between NF and platelets might be reduced. This is considered to be the reason why platelet adhesion and activation was suppressed significantly on NF.
In this study, we evaluated peripheral circulation by SPP which is a method measuring non-invasively dermal microcirculation by using Laser Doppler imaging-based methods because there are many reports describing them being useful to evaluate peripheral circulation disturbance such as lower limb ischemia in hemodialysis patients [7, 8]. Evaluation of the SPP suggested that peripheral circulation was more stable during dialysis with NF (Fig. 8). Additionally, dialysis-related side effects tended to be reduced in patients who continued using NF for 3 months (Fig. 9). Previous articles have reported the improvements of various clinical symptoms with the conventional PMMA dialyzers [3-5, 9-19]. Protein adsorption by PMMA membranes is considered one factor associated with these improvements. However, on BG, platelets also tend to adhere and be activated. Activated platelets induce the aggregation of platelets alone, platelets and leukocytes together, and platelets, leukocytes, and erythrocytes, which can interfere with peripheral circulation during dialysis [20, 21]. Deteriorated peripheral circulation causes dialysis-related side effects, including muscle cramps and abdominal pain during and after dialysis and fatigue after dialysis. Recently, the problem of dialysis-related side effects as factors affecting the prognosis of dialysis patients has gained attention from researchers [22-24], who have tried to identify the importance of dialysis prescriptions for reducing side effects [5]. On the other hand, in dialysis patients, aggregates of platelets and leukocytes remain in the serum even after dialysis and are associated with poor prognosis of these patients [25]. Improved platelet activation in NF may be significant in improving the prognosis of patients, as well as reducing the frequency of side effects.

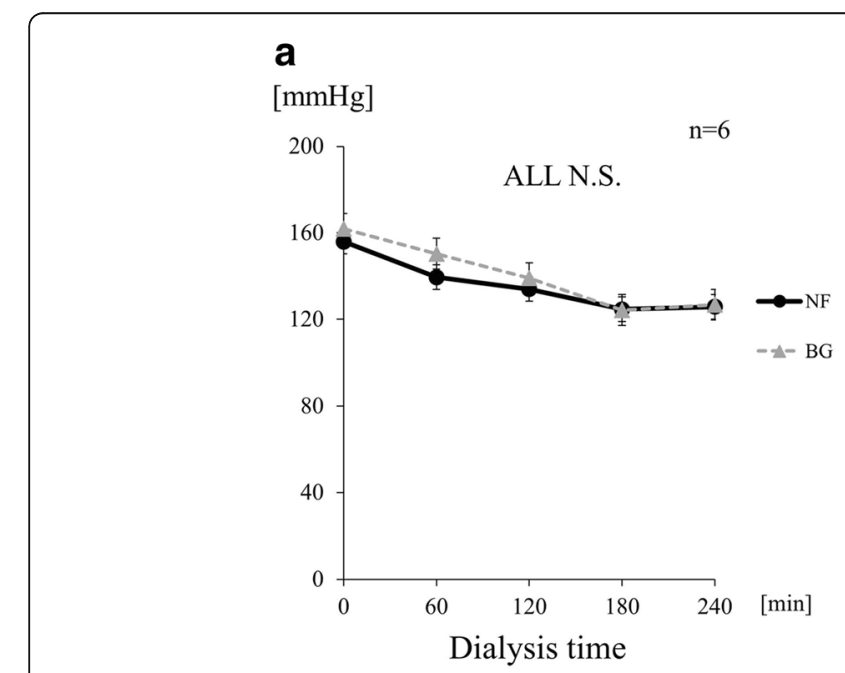

\section{b}

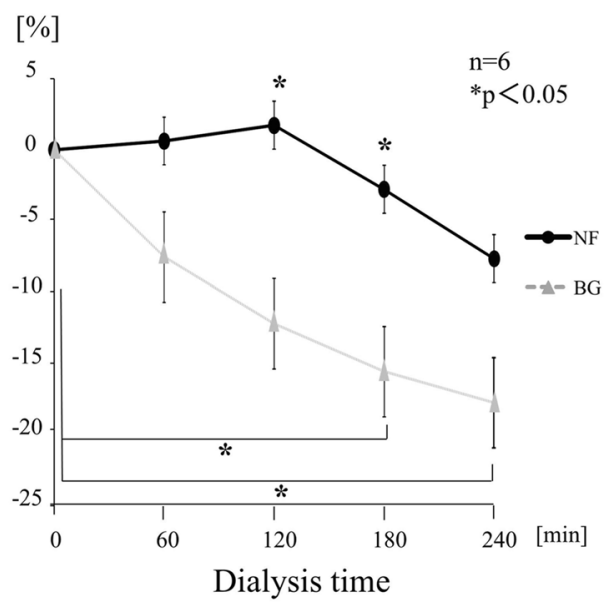

Fig. 8 The percent changes during dialysis with NF and BG. a Systolic blood pressure. b SPP 


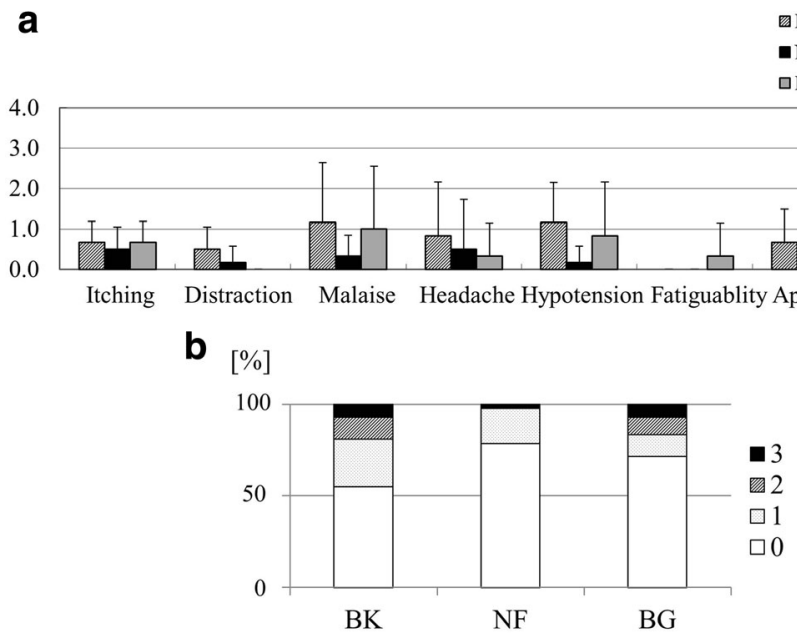

Fig. 9 The results of investigation of dialysis-related side effects under using PMMA dialyzers. a Score by item (mean \pm SD). b Frequency by score

\section{Conclusions}

The new PMMA dialyzer NF shows substantially improved hemocompatibility. We expect this product will improve the condition of chronic dialysis patients.

\section{Acknowledgements}

Not applicable.

\section{Funding}

IM received research funds from Toray Industries, Inc.

\section{Availability of data and materials}

All data generated or analyzed during this study are included in this article.

\section{Authors' contributions}

$H F, Y U$, and $H S$ performed the evaluations in vitro. IM, SE, AY, and TC performed the clinical study. IM was a major contributor in writing the manuscript. All authors read and approved the final manuscript.

\section{Competing interests}

Three of the authors (HF, YU and HS) are employees of Toray Industries, Inc. Four of the authors (IM, SE, AY, TC) are employees of Yabuki Hospital.

\section{Consent for publication}

Not applicable.

\section{Ethics approval and consent to participate}

Clinical study was approved by the ethical committee of Yabuki Hospital (Authorization No. 30), and documented informed consent was obtained from each patient.

\section{Publisher's Note}

Springer Nature remains neutral with regard to jurisdictional claims in published maps and institutional affiliations.

\section{Author details}

${ }^{1}$ Yabuki Hospital, Yamagata, Japan. ${ }^{2}$ Advanced Materials Research Labs, Toray Industries, Inc., 2-2 Sonoyama 3-chome, Otsu, Shiga, Japan.
Received: 24 December 2016 Accepted: 12 April 2017

Published online: 17 July 2017

\section{References}

1. Birk HW, Kistner A, Wizemann V, Schutterle G. Protein adsorption by artificial membrane materials under filtration conditions. Artif Organs. 1995;19(5):411-5.

2. Tomisawa N, Yamashita AC. Amount of adsorbed albumin loss by dialysis membranes with protein adsorption. J Artif Organs. 2009;12:194-9.

3. Kato A, Takita T, Furuhashi M, Takahashi T, Watanabe T, Maruyama Y, Hishida A. Polymethylmethacrylate efficacy in reduction of renal itching in hemodialysis patients: crossover study and role of tumor necrosis factor-a. Artif Organs. 2001;25(6):441-7.

4. Lin HH, Liu YL, Liu JH, Chou CY, Yang YF, Kuo HL, Huang CC. Uremic pruritus, cytokines, and polymethylmethacrylate artificial kidney. Artif Organs. 2008; 32(6):468-72.

5. Masakane I. High-quality dialysis: a lesson from the Japanese experience. NDT Plus. 2010;3(Suppl 1):i28-35.

6. Adera HM, James K, Castronuovo Jr JJ, et al. Prediction of amputation wound healing with skin perfusion pressure. J Vasc Surg. 1995;21:823-8.

7. Shimazaki M, Matsuki T, Yamauchi K, Iwata M, Takahashi H, Genda S, Ohata J, Nakamura Y, Inaba Y, Yokouchi S, Kikuiri T, Ashie T. Assessment of lower limb ischemia with measurement of skin perfusion pressure in patients on hemodialysis. Ther Apher Dial. 2007;11:196-201.

8. Hiratsuka M, Koyama K, Yamamoto J, Narita A, Sasakawa Y, Shimogushi H, Ogawa A, Kimura T, Mizuguchi K, Mizuno M. Skin perfusion pressure and the prevalence of atherothrombosis in hemodialysis patients. Ther Apher Dial. 2016;20:40-5.

9. Biasioli S, Schiavon R, Petrosino L, Cavallini L, Cavalcanti G, Fanti E, Zambello A, Borin D. Role of cellulosic and noncellulosic membranes in hyperhomocysteinemia and oxidative stress. ASAIO J. 2000;46:625-34.

10. Galli F, Benedetti S, Buoncristiani U, Piroddi M, Conte C, Canestrari F, Buoncristiani E, Floridi A. The effect of PMMA-based protein-leaking dialyzers on plasma homocysteine levels. Kidney Int. 2003;64:748-55.

11. Galli F, Benedetti S, Floridi A, Canestrari F, Piroddi M, Buoncristiani E, Buoncristiani U. Glycoxidation and inflammatory markers in patients on treatment with PMMA-based protein-leaking dialyzers. Kidney Int. 2005:67:750-9.

12. Niwa T, Asada H, Tsutsui S, Miyazaki T. Efficient removal of albumin-bound furancarboxylic acid by protein-leaking hemodialysis. Am J Nephrol. 1995;15:463-7.

13. Cohen G, Rudnicki M, Schmaldienst S, Horl WH. Effect of dialysis on serum/ plasma levels of free immunoglobulin light chains in end-stage renal disease patients. Nephrol Dial Transplant. 2002;17:879-83. 
14. Hata H, Nishi K, Oshihara W, Arai J, Shimizu K, Kawakita T, Nkamura M, Mitsuya $\mathrm{H}$. Adsorption of Bence-Jones protein to polymethylmethacrylate membrane in primary amyloidosis. Amyloid. 2009;16(2):108-10.

15. Contin C, Lacraz A, Precigout V. Potential role of the soluble form of CD40 in deficient immunological function of dialysis patients: new findings of its amelioration using polymethylmethacrylate (PMMA) membrane. NDT Plus. 2010;3(Suppl 1):i20-7.

16. Duranti E, Duranti D. Polymethylmethacrylate strengthens antibody response hemodialysis patients not responding to hepatitis vaccine: preliminary data. MINERVA MED. 2011;102:1-2.

17. Kuramochi $G$, Shima K. Reduction of hepatitis $C$ virus by dialysis membrane. J Artif Organs. 2001;4:146-9.

18. Kreusser W, Reiermann S, Vogelbusch G, Bartual J, Schulze E. Effect of different synthetic membranes on laboratory parameters survival in chronic haemodialysis patients. NDT Plus. 2010;3(Suppl 1):i12-9.

19. Aoike I. Clinical significance of protein adsorbable membranes-Long-term clinical effects and analysis using a proteomic technique. Nephrol Dial Transplant. 2007;22(Suppl 5):v13-9.

20. Sirolli V, Ballone E, Amoroso L, Liberato L, Mascio R, Cappelli P, Albertazzi A, and Bonomini M. Leukocyte adhesion molecules and leukocyte-platelet interactions during hemodialysis: effects of different synthetic membranes. Int J Artif Organs. 1999;22:536-542.

21. Sato M, Morita $H$, Ema $H$, Yamaguchi S, Amano I. Effect of different dialyzer membranes on cutaneous microcirculation during hemodialysis. Clin Nephrol. 2006;66:426-32.

22. Lopes AA, Albert JM, Young EW, et al. Screening for depression in hemodialysis patients: associations with diagnosis, treatment, and outcomes in the DOPPS. Kidney Int. 2004;66:2047-53.

23. Elder SJ, Pisoni RL, Akizawa T, Fissell R, Andreucci VE, Fukuhara S, Kurokawa K, Rayner HC, Furniss AL, Port FK, Saran R. Sleep quality predicts quality of life and mortality risk in haemodialysis patients: results from the Dialysis Outcomes and Practice Patterns Study (DOPPS). Nephrol Dial Transplant. 2008:23:998-1004.

24. Pisoni R, Wikstrom B, Elder SJ, Akizawa T, Asano Y, Keen ML, Saran R, Mendelssohn DC, Young EW, Port FK. Pruiritus in haemodialysis patients: international results from the Dialysis Outcomes and Practice Patterns Study (DOPPS). Nephrol Dial Transplant. 2006:21:3495-505.

25. Kobayashi S, Miyamoto M, Kurumatani H, Oka M, Maesato K, Mano T, Ikee R, Moriya $\mathrm{H}$, Ohtake T. Increased leukocyte aggregates are associated with atherosclerosis in patients with hemodialysis. Hemodial Int. 2009;13:286-92.

\section{Submit your next manuscript to BioMed Central and we will help you at every step:}

- We accept pre-submission inquiries

- Our selector tool helps you to find the most relevant journal

- We provide round the clock customer support

- Convenient online submission

- Thorough peer review

- Inclusion in PubMed and all major indexing services

- Maximum visibility for your research

Submit your manuscript at www.biomedcentral.com/submit
Biomed Central 